\title{
Overview of a Special Issue on "Geotectonic Evolution of the Japanese Islands under New Paradigms of the Next Generation (Part I-III)"
}

\author{
Junzo KASAHARA ${ }^{1)}$, Osam SANO ${ }^{2)}$, Nobuo GESHI $^{3)}$, \\ Yukio ISOZAKI ${ }^{4)}$, Shigenori MARUYAMA ${ }^{5)}$ and Shuichi YANAI ${ }^{6)}$
}

\begin{abstract}
This article provides an overview of papers collected in the special issue titled "Geotectonic Evolution of the Japanese Islands under New Paradigms of the Next Generation (Part I-III)" for international readers. Research on the geologic evolution of the Japanese Islands started from the geotectonic subdivision with definitions of elements and boundaries in the late 19th century. Traditionally, some remarkable faults, such as Median Tectonic Line (MTL), Fossa magna, and Tanakura Tectonic Line (TTL), were regarded as the most important; however, these apparent features were in fact formed during the Miocene opening of the Japan Sea, whereas the major structures of Japan were made by the Pacific-type orogenies throughout the Phanerozoic after the initiation of subduction at $520 \mathrm{Ma}$ (the Cambrian).

Marine geophysicists have realized that the formation of accretionary complex (AC) along modern active subduction zones is rather exceptional; instead, tectonic erosion takes place dominantly. The estimated addition rate of juvenile arc crust (composed of tonalite-tronjemite-granodiorite suite; TTG) is negative at present for the entire globe, i.e., the total volume of the continental crust is currently decreasing. This indicates that tectonic erosion must also have occurred effectively in the past, and that its geological remnants need to be investigated carefully. A possible proxy geologic body for ancient tectonic erosion is a serpentinite mélange, which often includes calc-alkaline volcanics and coeval high-P/T blueschists within serpentinite matrices as shown in the geology of Japan. The largescale shortening of a fore-arc crust can occur solely due to tectonic erosion, which may involve more than $150 \mathrm{~km}$-wide areas of missing rocks between volcanic arc and trench. The sporadic occurrence of tectonic blocks of older (520-150 Ma) TTG rocks in serpentinite mélange indicates that four arc crusts, out of the five made by Pacific-type orogeny in Japan during the past 500 million years, have already been consumed.

The Pacific-type orogeny was revisited after recent critical discoveries of; (1) orogenic core of high-P/T regional metamorphic belt as a thin $(<2 \mathrm{~km})$ solid high-T intrusion, bounded on the top and bottom by a paired fault; (2) rapid increase of 200-300 km-wide TTG belt formed by slab-melting; (3) these culminated with an approaching mid-oceanic ridge, associated with large-scale tectonic erosion; and (4) formation of an AC after ridge subduction and doming up of a sandwiched set of high-P belt
\end{abstract}

1) Institute of Geosciences, Faculty of Science, Shizuoka University, Shizuoka, 422-8529, Japan

2) Former Earthquake Research Institute, University of Tokyo, Tokyo, 113-0032, Japan

3) Geological Survey of Japan, AIST, Tsukuba, 305-8567, Japan

4) Department of Earth Science and Astronomy, The University of Tokyo, Tokyo, 153-8902, Japan

5) Department of Earth and Planetary Sciences, Tokyo Institute of Technology, Tokyo, 152-8551, Japan

6) Japan Geocommunications Co. Ltd., Tokyo, 160-0004, Japan 
and accretionary belt below and above. The Pacific-type orogeny has been ignored since the "terrane plague"; however, Pacific-type orogeny dominated to increase the TTG crust leading to the births of continents and supercontinent by $1.8 \mathrm{Ga}$. The extensive tectonic erosion and arc subduction through time, suggesting 10 times more TTG materials, enriched with radiogenic elements, floated at the bottom of the mantle transition zone, which generated heat to warm up the mantle up to $200 \mathrm{~K}$ within 100 million years in the Archean, and to $100 \mathrm{~K}$ in the Phanerozoic. Subducted TTG and presence of second continents in the mid-mantle may explain more general aspects of mantle dynamics, and the concept may become a frontier of solid Earth science in the 21st century.

From the viewpoint of the history of science, the previous geological studies in Japan since the Meiji Era are also summarized briefly, with special reference to the orogeny, tectonics, and geotectonic subdivision of the Japanese Islands.

Key words : Pacific-type orogeny, tectonic erosion, second continent, geotectonic evolution of Japan, frontier in solid Earth science

\section{Introduction}

This special issue titled "Geotectonic Evolution of the Japanese Islands under New Paradigms of the Next Generation (Part I-III)" introduces various recent progresses in the orogenic studies and relevant geotectonic subdivision of Japan, the ca. 600 million year-old archipelagos in Far East Asia. The conventional geotectonic model for the evolving Pacific-type orogenic belts in Japan is as follows; after the breakup of the Proterozoic supercontinent Rodinia, Japan was born near the Yangtze (South China) craton. Proto-Japan changed from a passive margin to an active Pacific-type margin around $500 \mathrm{Ma}$, and has grown oceanward for $c a .500 \mathrm{~km}$ with the successive oceanic subduction from the Pacific side. Its oceanward growth was intermittent as punctuated by at least four orogenic peaks that produced four sets of regional high-P/T metamorphic belt and granitic batholith. Between these orogenic peaks, accumulations of large amounts of accretionary complex (AC) widened the arc-trench system. This scenario, however, is currently being challenged by new data and by new perspectives on the subductionrelated process called tectonic erosion, which was originally proposed by marine geophysicists in the 1990s. This special issue introduces the current aspects of orogenic studies in Japan, with particular emphasis on tectonic erosion. Articles collected in this special issue are classified into the following six major categories; (1) geotectonic subdivision of the Japanese Islands, (2) geotectonic history, (3) review of tectonic erosion and implications for on-land geology, (4) Pacific-type orogeny revisited, (5) granite subduction as a cutting edge concept in solid Earth science, and (6) research history of geology in Japan.

\section{Geotectonic Subdivision of the Japanese Islands}

As illustrated in the first geologic map of Japan (Naumann, 1885), Edmund Naumann (18541927; Fig. 1) clarified the fundamental characteristics of the geology of the Japanese Islands during his 10-year stay at the beginning of the Meiji Era. The geotectonic subdivision of Japan was characterized by the along-arc zonal arrangement of narrow geologic units traditionally called belts, which were differentiated from each other by their rock type and megafossil age. The two most striking tectonic boundaries in Japan first recognized by Naumann were Fossa magna in central Japan, which divides NE Japan from SW Japan, and the Median Tectonic Line (MTL) in SW Japan, which divides the continent side (Inner zone) from the ocean side (Outer zone) of SW Japan arc.

In addition to these two, the Tanakura Tectonic Line (TTL) in NE Japan, and assumed Western Kyushu Tectonic Line represent two remarkable tectonic features that define the eastern and west- 


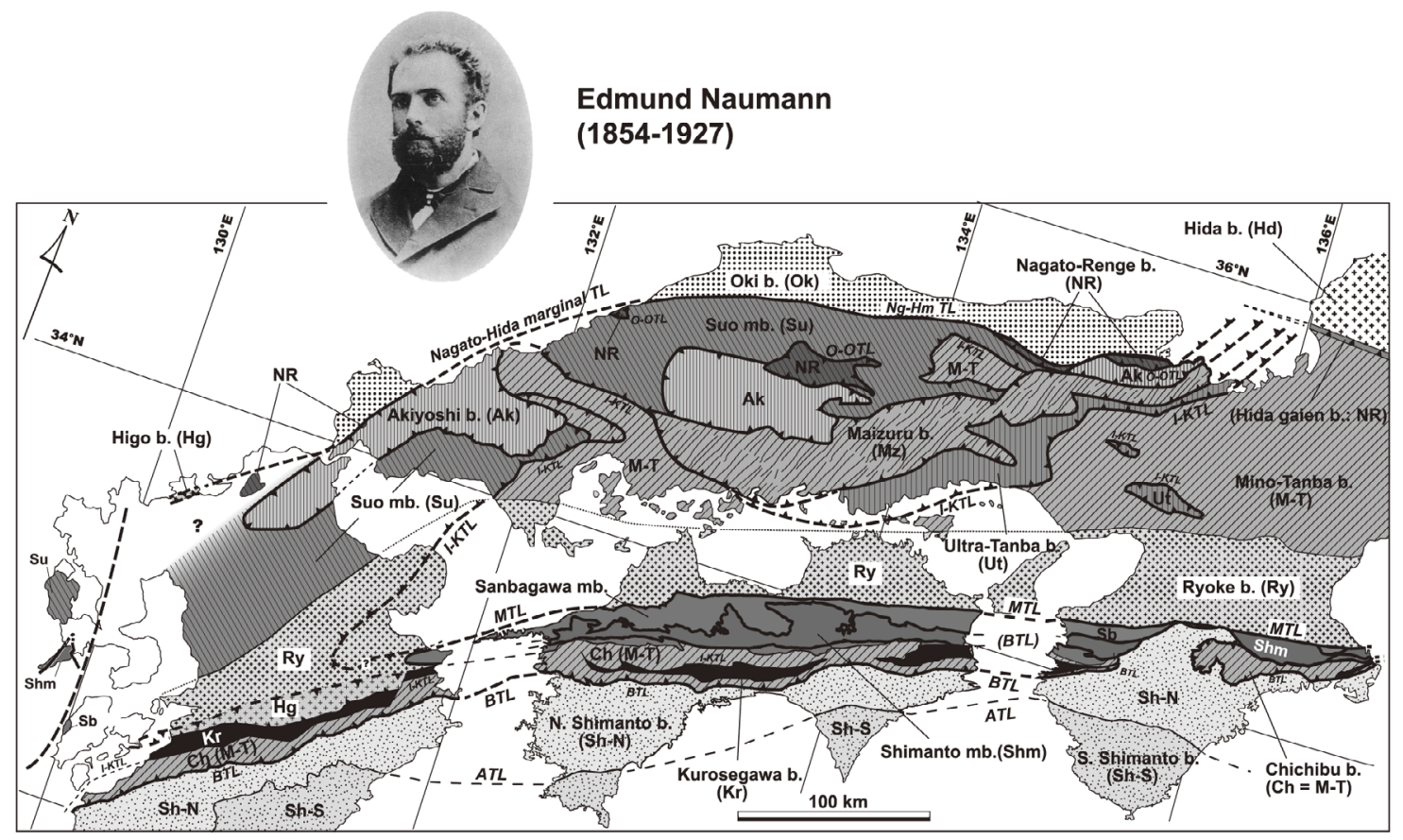

Fig. 1 Newly proposed geotectonic map of SW Japan together with a portrait of the pioneering German geologist, Edmund Naumann (1854-1927), who became the first geology professor at the University of Tokyo and then the first director of the Geological Survey of Japan, immediately after the establishment of modern Japan.

ern margin-bounding faults of the back-arc basin, the Japan Sea that opened during the Miocene. These apparently linear faults have been regarded to be the most important tectonic features of Japan for a long time; however, they are too young to constrain the overall orognic framework of Japan, which can be traced back to $600 \mathrm{Ma}$, as already mentioned by Kobayashi (1941) and many others (e.g., Yanai et al., 2010). Instead, these faults merely represent Miocene micro-plate boundaries; e.g., Fossa magna as Miocene ridge-transform fault system, and MTL as a fore-arc contracting boundary within SW Japan during the opening of the Japan Sea.

Although less conspicuous when identified in the field, more important and critical boundaries of neighboring orogens were later proposed by Isozaki and Itaya (1991), and thereafter by Isozaki and Maruyama (1991), with special reference to the upper and lower boundary faults between unmetamorphosed accretionary complexes (AC) and/or high-P/T metamorphosed AC units. The latest data and new perspectives obtained from the detrital zircon chronology suggest we need to pay more attention to serpentinite mélange belts that define large age-gaps within the multiple stacks of AC, high-P/T AC, or ophiolites belts. Serpentinite mélange belts often contain tonalitetronjemite-granodiorite (TTG) and related rocks, together with coeval $\mathrm{AC}$ and also jadeite/ glaucophane-bearing blueschists, although all in small amounts. The mixing of these rocks indicates severe shortening of a past fore-arc crust between deep-subduction zone and volcanic front, in other words, the largest-scale tectonic erosion to juxtapose rocks of trench and volcanic arc, extending over $150 \mathrm{~km}$ wide. Serpentinite mélange belts occur as a subhorizontal klippe on the top in SW Japan, where ca. 580 Ma ophiolite occurs as the oldest unit in Japan. On the basis of the latest data, in particular, the detrital zircon chronology obtained by laser-ablation inducedcoupled-plasma mass spectrometer (LA-ICP-MS) rapid analysis (Nakama et al., 2010), the geotec- 


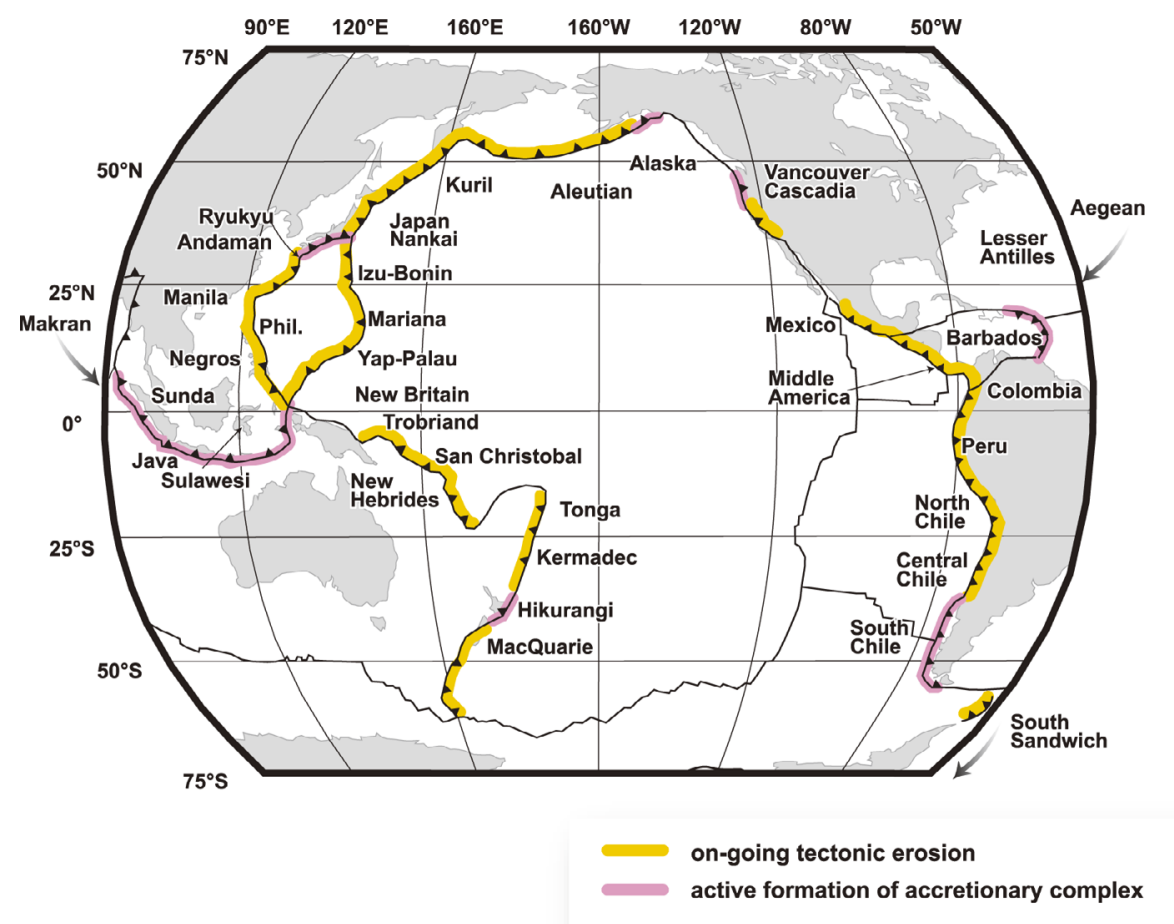

Fig. 2 Accretionary versus erosional margins around the Pacific (after Scholl and von Huene, 2007). Note the dominance of tectonic erosion over accretion along the circum-Pacific active continental margins.

tonic subdivision of Japan is thoroughly revised here, together with a brief review of fundamental problems of the traditional geotectonic studies in Japan (Isozaki et al., 2010b) .

\section{Tectonic Erosion: \\ Review and Examples of On-Land Japan}

In general, modern subduction zones form a few ACs at the inner walls of active trenches; instead, active tectonic erosion takes place dominantly with possibly three different processes; i.e. (1) direct transportation of trench-fill turbidites into the mantle as graben-filled sediments on the oceanic plate, (2) destruction of topographic highs, such as horst wall, seamount and others, along the hanging wall of trench inner wall and ceiling above descending slab, and (3) tectonic overpressure due to dehydration of descending hydrated slabs. Yamamoto (2010) reviews the current status of studies on tectonic erosion (Fig. 2). The pioneering work of von Huene and Scholl
(1991) and Clift et al. (2009) assumes that intraoceanic arcs are all accreted to the continental margin, and never subduct into the mantle. Yamamoto et al. (2009) have demonstrated that five intra-oceanic arcs are being subducting under SW Japan without accretion against the hanging wall. From these observations, he estimates the growth of the continental crust to be negative, which differs from the previous estimates.

Hirata et al. (2010) summarize the most representative example of the Proto-Izu-Mariana arc collision against Honshu arc since $15 \mathrm{Ma}$, and concluded that tectonic erosion of Honshu arc occurred, i.e., about $50 \%$ of the arc crust was subducted during the last $15 \mathrm{Ma}$. Ongoing tectonic erosion is observed at the arc-trench gap off Mariana, where serpentinite mélange belt is currently forming, which includes glaucophanebearing high-P/T schists and almost coeval arc calc-alkaline volcanics together. 


\section{Geotectonic History of the Japanese Islands}

On the basis of an ocean plate stratigraphy by micro-fossil dating (OPS) analysis of ancient ACs, the tectonic history of the Japanese Islands was drastically revised by Isozaki and Maruyama (1991) nearly two decades ago. They showed a generalized scenario of successive oceanward growth of the Japanese Islands punctuated by several episodic intrusions of TTG and exhumation of high-P/T metamorphic belt. A recent summary of ACs in space and time in Japan, however, clearly shows discontinuous growth and huge age gap in formation; nearly $2 / 3$ of the last 520 million years correspond to the missing period of ACs.

The oldest geotectonic unit of Pacific-type orogen in Japan is Omi district, central Honshu, Japan, and is summarized geologically by Kunugiza et al. (2011). Its main unit composed of 360$340 \mathrm{Ma}$ glaucophanitic metamorphic rocks still preserves the original thermobaric structure; i.e., the highest grade part up to the eclogite facies is sandwiched between the lowerer-pressure rocks (Matsumoto et al., 2011), although the upper and lower boundaries were strongly modified by later tectonics.

A unique geologic unit of the $240-230 \mathrm{Ma}$ intermediate-pressure type metamorphic belt in Japan corresponds to the eastern extension of the Triassic collision belt in China; i.e. the collision suture between N. China and S. China cratons with ultrahigh-pressure (UHP) rocks such as coesite-bearing eclogite (Wang et al., 1989). In addition to as unique UHP-HP metamorphism, their protoliths are quite different from Pacific-type orogens, because bedded chert of deep-sea sediments and pure carbonate of seamount-top-limestone are characteristic in the former, while platform sediments such as impure carbonate, per-aluminous sediments are characteristic in the latter. This collision-marker unit runs sporadically in Japan suggesting that the Japanese Islands belong to the southern margin of the S. China carton, with the exception of the Hida-Oki belt with 1.9-2.0 Ga rocks, and rests on the structural top (Omori and Isozaki, 2011).
Santosh and Senshu (2011) discuss the pre-240 $\mathrm{Ma}$ (Paleozoic and older) history of Japan with respect to the S. China and N. China cratons. The Oki-Hida belts in SW Japan originally belonged to the N. China craton, and their history can be traced back to $1.8-2.0 \mathrm{Ga}$ as a periphery of Laurentia, which was a first supercontinent on the Earth. The S. China craton has a history going back to the Grenvillian time $c a .1 .0 \mathrm{Ga}$, when the supercontinent Rodinia was formed. After the breakup of Rodinia, the S. China craton was isolated in a super-ocean and migrated northward to be incorporated into a marginal part of the supercontinent Gondwana.

Suzuki et al. (2010) proposed a new scenario of the tectonic history of the Japanese Islands for SW Japan and NE Japan, based on the new idea that serpentinite mélange belts mark the largest-scale of tectonic erosion, with an arc-trench gap over $150 \mathrm{~km}$ tectonically missed by tectonic erosion, if this belt includes both TTG and related units along the vertical section of the volcanic front, and jadeite-glaucophane type schists formed directly above the Wadati-Benioff plane. Suzuki et al. conclude finally that the Japanese Islands have developed five arc crusts, but have already lost four of them to tectonic erosions, suggesting that those must now be identified under East Asia. A new mechanism of tectonic erosion was proposed, stressing the role of serpentinite in transporting tectonic blocks together with descending slab.

Arc-arc collision orogeny is taking place at the Izu-Honshu collision zone. Hirata et al. (2010) summarizes the collision-zone to the north of Izu, and concluded that several accreted fragments of the Proto-Izu arc date back to $15 \mathrm{Ma}$, and the ongoing plate boundary of PHS plate against Honshu arc (Eurasia plate) is the Kan-nawa fault along the Tokyo-Nagoya Highway to the north of the Izu Peninsula. It should be emphasized that the southern half of the Honshu arc has been tectonically eroded out by the collision of Izu arc since $15 \mathrm{Ma}$. Moreover, the Proto-Izu arc was as long as over $1000 \mathrm{~km}$ before the collision of Tanzawa block at $6 \mathrm{Ma}$, and subducted almost all parts with the exception of minor fragments. Recent tectonic erosion off NE Japan and Hok- 
kaido, off SW Japan and off Izu-Mariana arc were summarized, and the ongoing largest scale of tectonic erosion is off the Mariana arc where one arc was lost and blueschists and arc basalts coexist with serpentinite belt.

Paleogeographic reconstruction of the Japanese Islands was revised by Isozaki et al. (2011) where several episodes of tectonic erosions were included in the new data sets such as zircon age population diagrams by Nakama et al. (2010).

\section{Pacific-type Orogeny Revisited}

As for the definition, Pacific-type orogeny was originally proposed as Cordilleran-type orogeny (Fig. 3) by Dewey and Bird (1970), who clearly distinguished it from the contrasting collision-type orogeny. By emphasizing the synonymous nature of Cordilleran-type orogen to the paired metamorphic belts proposed by Miyashiro (1961), Matsuda and Uyeda (1971) renamed the Cordilleran-type as Pacific-type because of its dominance in the circum-Pacific regions rather than as restricted to western North America. As already pointed out by Dewey and Bird (1970), Pacific-type (Cordilleratype) orogeny accompanies the formation of huge batholith belts; e.g., Phanerozoic orogens in the circum-Pacific region are characterized by huge batholith belts, whereas they are virtually absent in collision-type orogens, such as in the Himalayas and Alps. Also emphasized for the Pacific-type was mélange formation by mixing oceanic material with continental terrigenous clastics (trench-fill turbidite) in front of the descending oceanic plate.

During the late 1970 s to the early 1980 s, regional microfossil (conodont and radiolaria) mapping, together with ocean plate stratigraphy (OPS) analysis in a bed-by-bed manner, made remarkable progress in anatomical studies of the on-land exposed Pacific-type orogen in Japan (e.g., Yamato-Omine Research Group, 1981; Matsuda and Isozaki, 1991). Applying this scheme, the ages of ancient subducted slabs and timings of ridge subduction were also estimated in California (e.g., Sedlock and Isozaki, 1990; Isozaki and Maruyama, 1992; Isozaki and Blake, 1994). At the same time, major structures of past orogen were reconstructed as a full set of four essential com- ponents; i.e., an $\mathrm{AC}$ formed at a trench, a high-P/ $T$ regional metamorphic belt in a deep subduction zone (as an orogenic core sandwiched between unmetamorphosed units above and below), a huge batholith belt beneath a volcanic arc, and a forearc basin between arc and trench. On the basis of the geological structures and relevant P-T paths of the metamorphosed thin unit, the idea of a slabmodel for a regional metamorphic belt, less than 2 $\mathrm{km}$-thick in general, appeared, together with the concept of sub-horizontal high-T intrusion into a low-pressure AC domain, i.e., the exhumation of high-P/T units (Maruyama, 1990; Maruyama et al., 1996).

The major causes of Pacific-type orogeny, however, remained unresolved. It was previously believed to occur in a steady-state mode, as observed in modern NE Japan where active calcalkaline volcanism occurs to increase the TTG crust over time. Nonetheless, the formation of a batholith belt, as well as exhumation of a regional metamorphic belt, did not occur in a steady-state manner. A comparison of paleogeography in the Pacific Ocean, records of AC in Japan, and age of batholith belt indicates that ridge subduction was the main driving mechanism of Pacific-type orogeny (Maruyama, 1997). Accordingly, a major cause of the episodicity of Pacific-type orogeny was consequently explained as intermittent ridgesubduction.

At the dawn of the plate tectonics era, Dewey and Bird (1970) proposed the provocative idea that the presence of ophiolites in orogenic belts indicates the past presence of a huge ocean such as the size of the modern Pacific, Atlantic, or Indian oceans. Since then, a series of research studies on ophiolites, not only by igneous and metamorphic petrologists, but also by isotope geochemists, paleontologists, and structural geologists, all followed up on his idea. This classic idea soon started to fall apart, however, since the first realization by Miyashiro (1973) that the world-famous Troodos ophiolites in Cyprus formed in an island arc not in a mid-oceanic ridge. Recently, most geologists admit that ophiolites often form primarily in-situ at arc settings as authochthonous units, not as allochthonous blocks/sheets as previously imagined 


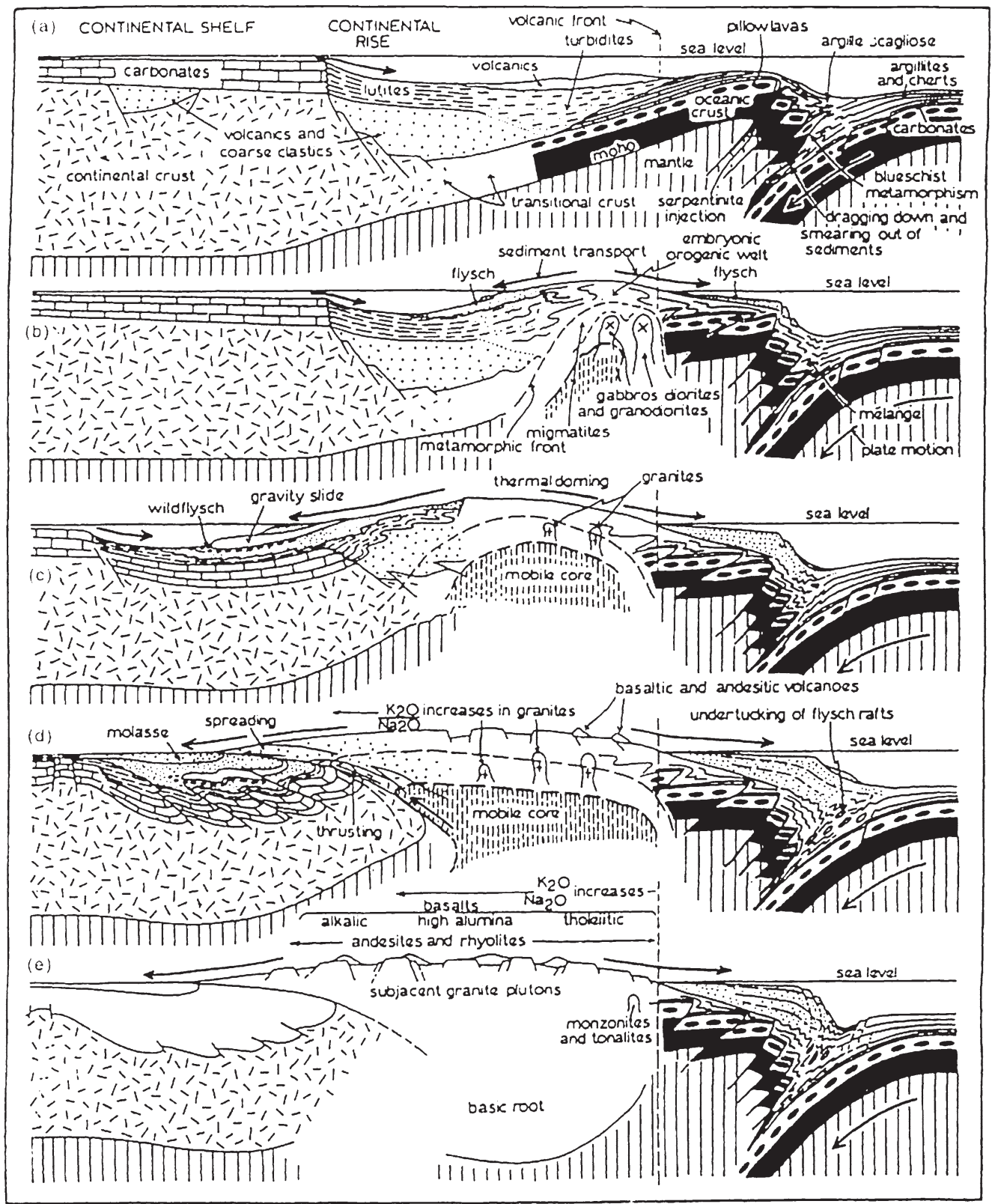

Fig. 3 Classic concept of Cordilleran-type (Pacific-type) orogeny of Dewey and Bird (1970). This diagram is called the "Deweygram" in honor of his pioneering work.

(Dilek and Newcomb, 2003).

Ishikawa et al. (2011) summarized the modes of occurrence of ophiolites in the western Pacific domain where numerous ophiolites were already exposed on land, and some still remain in small oceanic basins, such as the fore-arc basin (Weber Deep). It is particularly noteworthy that some ophiolites were emplaced on top of the world's youngest orogen with high-P/T metamorphic rocks to the west (Timor-Tanimber region). They 
concluded that ophiolites are petrologically diversified, thus probably are diversified in origin, such as back-arc basin, fore-arc basin, and possibly mid-oceanic ridge. Sophisticated analyses of trace element and isotope geochemistry will hopefully identify their origins.

The ongoing orogeny of the Japanese Islands is also unique, although the mid-oceanic ridge is not being subducted off NE Japan at present. Sakuyama (2010) reviews calc-alkaline volcanism of NE Japan, and concludes that arc basalt was derived directly from a parental magma, then was diversified by magma mixing with crustal components involving fluid migrations from the descending Pacific slab underneath. Nakamura and Iwamori (2010) showed geochemical signatures that illustrate the contrasting nature of arc volcanoes between NE and SW Japan, where the old Pacific plate and the young Philippine Sea plate have been subducting over 20 m.y., respectively, to generate the mutually contrasting geochemical signatures.

Pacific-type orogeny over time is reviewed by Maruyama et al. (2011) who settle long-lasting debates over definitions and extents, and provide future perspectives in terms of space and time, although the Pacific-type was ignored when the suspect terrane concept predominated during the late 1970s (e.g., Coney et al., 1980). Instead of ridge subduction, the collision of an aseismic ridge, such as huge oceanic plateaus in the Pacific, was regarded to be critical for orogenic growth, and the collision-almighty interpretation was too much emphasized (Nur and Ben-Avraham, 1982). Amidst this terrane plague, most geologists around the world seemed to forget about Pacifictype orogeny, and the major orogenic belts of the Caledonides, Hercynides, and Alpides in Europe, and the Appalachian belt in USA have been explained solely in terms of collision tectonics. On the other hand, the pre-existing Pacific-type orogeny prior to the final continental collision has been completely ignored. A typical example of a collision belt in the United Kingdom, however, is given here to stress the importance of Pacifictype orogeny over time. The entire UK was in fact formed mostly by Pacific-type orogeny simply because a $200-300 \mathrm{~km}$-wide batholith belt could be formed solely by the pre-collision Pacific-type subduction processes under the Avalonia (western Africa) continental block. Three belts of Pacifictype orogeny between the Scotland (Laurentia) and Avalonia continents are recognized. The most important and critical is evidence of extensive tectonic erosion. The proxy geologic unit is a serpentinite mélange that includes both blueschist and nearly coeval calc-alkaline rocks within the serpentinite matrix. Extending the regional geology from the UK to eastern North America and Africa, the site of the subduction of huge amounts of TTG materials corresponds to the domain in the central part of Pangea. This localized concentration of continental materials within the mantle might trigger the first spreading under the supercontinent and open the mid-Atlantic Ocean.

Tectonic erosion is a surface process that erodes the frontal portion of the hanging plate, but may give the impression of having no significance for surface geology as it might represent the disappearance of some orogenic components. Tectonic erosion, however, supplies huge amounts of selfheat-generating TTG materials into the mantle, which probably controls surface plate tectonics.

The geology of the Japanese Islands records a tectonic history younger than $520 \mathrm{Ma}$, thus it appears unlikely to be suitable for discussing Precambrian orogeny in general. However, some work has been done by Japanese geologists (e.g., Komiya et al., 1996; Kitajima et al., 2001) who studied several representative Archean regions of the world, e.g., Isua in Greenland, Western Pilbara craton, central Canada, and South Africa. Having summarizing all of such recent work, it becomes apparent that most of the Archean orogenic belts are of the Pacific-type because no large continents were present at that time. Embryonic continents appeared on the surface due to parallel collisions of intra-oceanic arcs and resultant growth of primitive continents at $1.8-1.9 \mathrm{Ga}$, which is clear on a geologic map of North America (Hoffman, 1989). Therefore, we can conclude that Pacifictype orogeny also dominated in the Archean to Early Proterozoic Earth. 

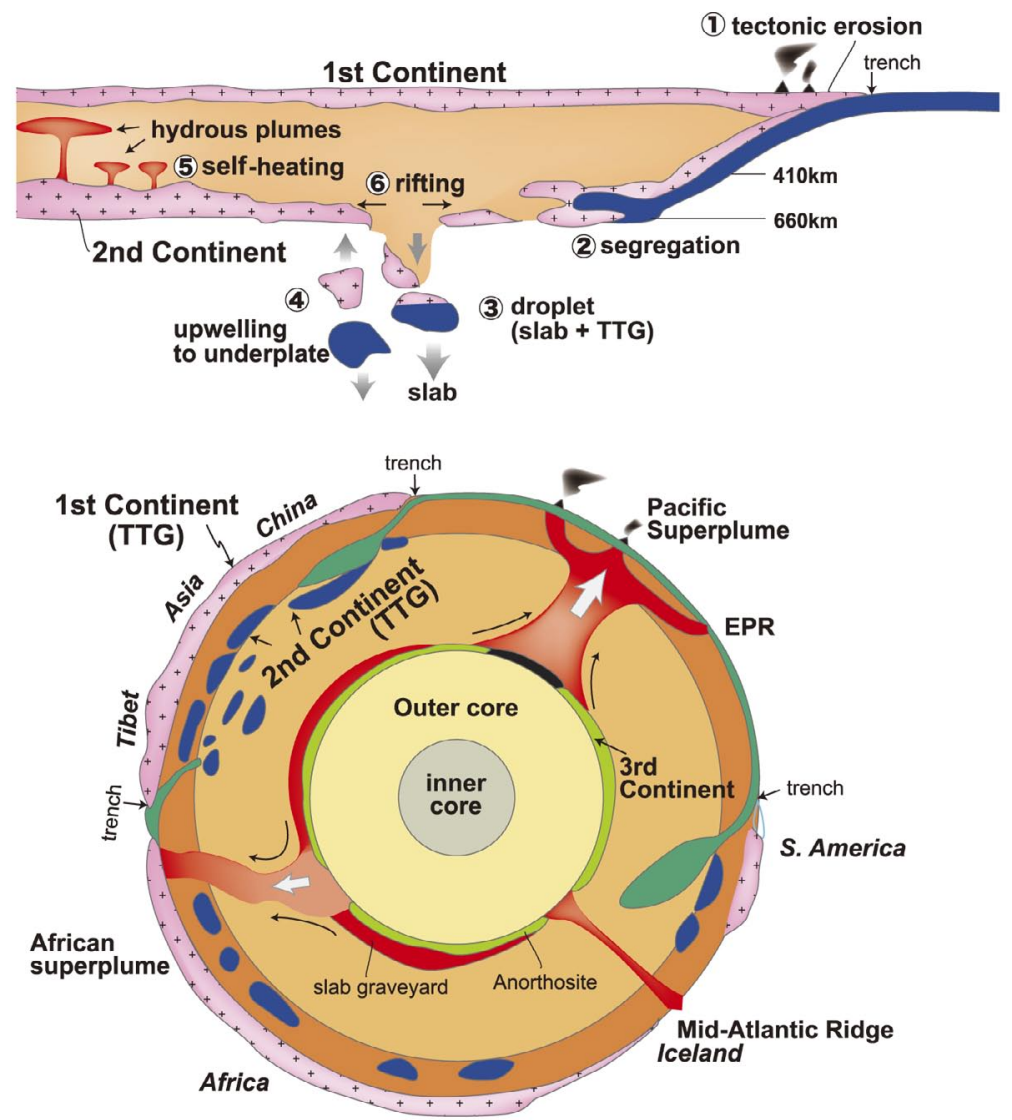

Fig. 4 The revised Pacific-type orogeny, including tectonic erosion, which bridges surface geology to mantle dynamics (above). Above: Tectonic erosion transports TTG materials into the mantle transition zone (1), where TTG materials are segregated to form the second continents (2). Stagnant slabs including TTG materials finally become unstable to collapse into the lower mantle if TTG materials are separated from the down-going slab avalanches (3), TTG materials underplate at $660 \mathrm{~km}$ deep, the mantle transition zone (4). Accumulated TTG materials with self-heating grow the second continents, and warm up the hydrous mantle transition zone to generate the hydrous plumes (5) to cause smallscale rifting to yield marginal basins (6). The cause of the stagnant slabs in the western Pacific to eastern Asia may be the presence of second continents to prevent slab penetration. Below: The distribution of the second continents along the cross section of the solid Earth (modified from Maruyama et al., 2007). The second continents are concentrated under Asia, reflecting the history of Asia back to $300 \mathrm{Ma}$. Also note the distribution of the third continents (anorthosite) right above the core-mantle boundary at 2,900 km deep. See Kawai et al. (2009) for details.

\section{Granite Subduction: Frontier of Solid Earth Sciences}

After the terrane plague waned, many geologists working on orogeny seemed to lose their way for nearly two decades. Pacific-type orogeny, however, can provide a new roadmap for bridge geophysics and geology of crust/mantle material circulation. Following the summary of tectonic erosion by Yamamoto (2010), Kawai et al. (2010) calculated density changes of granite from the surface to a depth of $660 \mathrm{~km}$ in the mantle, and conclude that granite is heaviest in the upper mantle below a depth of $200 \mathrm{~km}$ where the phase change of $\mathrm{SiO}_{2}$ phase to stishovite occurs. Comparing the P-wave velocity with PREM from the surface to the center of the Earth, they concluded that 6-7 times more granitic materials must be present at the bottom of the upper mantle in the 520-660 km depth range. Maruyama et al. (2010) showed the distribution patterns of second continents in the mantle transition zone (Fig. 4), 
based on P-wave whole mantle tomography by Zhao (2008). They count 26 in total that occur only under East Asia-New Zealand, and under NW USA and mid-S. America, but are absent in the major Pacific, Indian, and Atlantic oceans. The distribution of these second continents reflects the history of continent subduction, and the history of horizontal tectonics in the mantle transition zone, which is related to the supercontinent cycle called the Wilson Cycle.

Related to the second continents, all of the third continents on the core/mantle boundary (CMB), presumably anorthosite (Kawai et al., 2009) and superplume, would seem to be connected to each other, and are the next target to be investigated in detail through interdisciplinary studies in the near future. Senshu et al. (2010) briefly review the numerical simulation of mantle convection, and propose the next target, incorporating TTG as a self-heating unit within the mantle, showing their preliminary calculation in a box model. About 200 m.y. rises $c a .200 \mathrm{~K}$ at the interface of the overlying mantle in the Archean and $100 \mathrm{~K}$ in the Phanerozoic. These values are large enough to trigger new mantle convection at a depth of 410 $\mathrm{km}$.

On the other hand, the question as to whether or not a magma ocean remains at the CMB seems to be a general frontier around the world. We predict that TTG in the mantle in space and time will be next frontier in solid Earth science.

\section{Research History of Earth Science in Japan}

New paradigms of plate tectonics started to be imported from Europe and the USA into Japan in the early 1970s, and a general scheme of how to reconstruct the tectonic development of the Japanese Islands was introduced first by Horikoshi (1972), following the template originally proposed by Dewey and Bird (1970). Immediately after the Horikoshi (1972) model, the marginal basin model and other variants appeared (e.g., Ichikawa et al., 1972). The core of the template of Dewey and Bird (1970) is the presence of ophiolites or serpentinite belts in orogenic belts. Although Dewey and Bird's (1970) proposal has had a great impact on geology, how to reconstruct the tectonic history of orogenic belts in principle, e.g., origin of ophiolites as exotic or in situ, ten-plate applications to the Japanese Islands were ad hoc, and represent a typical example of the colonial science stage of G. Basalla (Isozaki et al., 2010a). In other words, ad hoc work did not bear any fruit afterwards according to the progressive research program of I. Lakatos.

Maruyama et al. (2010) undertook a new review of the history of geological research in Japan as to whether or not the concept of Lakatos' progressive research program was valid, e.g., in petrogenesis of arc magma particularly after the model proposed by Tatsumi et al. (1983). Similarly, metamorphic petrology is also discussed after the discovery of UHP-HP metamorphism in collision orogens and also the Pacific-type as an example of the Cretaceous Sanbagawa belt, Japan.

\section{Future Research}

The new aspects presented above that have been recently revealed in Japan guarantee a rapid change in the geological understanding of subduction-related orogenic belts in time and space. It is also emphasized here that the latest information from the surface geology of Japan consequently demands remarkable reconsideration of conventional global tectonics; i.e., subduction of continental crust and mantle convection.

Ever since Naumann, geological studies in Japan have been too dependent on knowledge and techniques imported from the western countries. After a long period of experience of the non-science and colonial science stages proposed by Basalla (1967), the status of Japanese geologists and geological communities had already reached the independent science stage at the end of the last century. Now, in the early $21^{\text {st }}$ century, we are standing in front of the gate of the more advanced stage of exporting science (Isozaki et al., 2010a). We hope this special issue will benefit many researchers in Earth science not only in Japan but also in the rest of the world. 


\section{Acknowledgements}

The editorial committee of this special issue would like to thank all of the contributors to this unique collection of cutting-edge articles.

\section{References}

Basalla, G. (1967): The spread of western science. Science, 156, 611- 622.

Clift, P.D., Vannucchi, P., and Morgan, J.P. (2009): Crustal redistribution, crust-mantle recycling and Phanerozoic evolution of the continental crust. EarthScience Review, 97, 80-104.

Coney, P.J., Jones, D.L. and Monger, J.W. (1980): Cordilleran suspect terranes. Nature, 288, 329-332.

Dewey, J.F., and Bird, J.M. (1970): Mountain belts and the new global tectonics. Journal of Geophysical Research, 75, 2625-2647.

Dilek, Y. and Newcomb, S. (2003): Ophiolite Concept and the Evolution of Geological Thought. Geological Society of America Special Paper, 373, 470p.

Hirata, D., Yamashita, H., Suzuki, K., Hirata, T., Li, Y-b. and Kon, Y. (2010): Collision accretion tectonics of proto-Izu-Mariana arc: A review. Journal of Geography (Chigaku Zasshi), 119, 1125-1160.

Hoffman, P.F. (1989): Precambrian geology and tectonic history of North America. in The Geology of North America-An Overview edited by Bally, A.W. and Palmer, A.R., Geological Society of America, 447-512.

Horikoshi, E. (1972): Orogenic belts in Japan and plate. Kagaku, 42, 665-674. (in Japanese.)

Ichikawa, K., Matsumoto, T. and Iwasaki, M. (1972): Evolution of the Japanese Islands. Kagaku, 42, 170181. (in Japanese.)

Ishikawa, A., Kaneko, Y., Ota, T. and Isozaki, Y. (2011): Ophiolites in the non-volcanic Banda outer arc of East Indonesia: Field occurrence and petrological variety of the world's youngest ophiolite. Journal of Geography (Chigaku Zasshi), 120, in press.

Isozaki, Y. and Blake, M.C.Jr.. (1994): Biostratigraphic constraints on formation and timing of accretion in a subduction complex: An example from the Franciscan complex in northern California. Journal of Geology, 102, 283-296.

Isozaki, Y. and Itaya, T. (1991): Pre-Jurassic klippe in northern Chichibu Belt in west-central Shikoku, Southwest Japan: Kurosegawa Terrane as a tectonic outlier of the pre-Jurassic rocks of the inner zone. Journal of the Geological Society of Japan, 97, 431450.

Isozaki, Y. and Maruyama, S. (1991): Studies on orogeny based on plate tectonics in Japan and new geotectonic subdivision of the Japanese Islands. Journal of Geography (Chigaku Zasshi), 100, 697-761.

Isozaki, Y. and Maruyama, S. (1992): New geotectonic subdivision of the Franciscan-Klamath region redefined by formation age of accretionary complexes.
American Association of Petroleum Geology Bulletin, $\mathbf{7 6}, 423$.

Isozaki, Y., Maruyama, S. and Yanai, S. (2010a): At the stage of "Exporting Science": A historical review of studies on the geotectonic subdivision and orogeny of the Japanese Islands. Journal of Geography (Chigaku Zasshi), 119, 378-391.

Isozaki, Y., Maruyama, S., Aoki, A., Nakama, T., Miyashita, A. and Otoh, S. (2010b): Geotectonic subdivision of the Japanese Islands revisited: Categorization and definition of elements and boundaries of Pacifictype (Miyashiro-type) orogen. Journal of Geography (Chigaku Zasshi), 119, 999-1053.

Isozaki, Y., Maruyama, S., Nakama,T., Yamamoto, S. and Yanai, S (2011): Alternating growth and shrink of an active continental margin: Updated geotectonic history of the Japanese Islands. Journal of Geography (Chigaku Zasshi), in press.

Kawai, K., Tsuchiya, T., Thuchiya, J., and Maruyama, S. (2009): Lost primordial continents. Gondwana Research, 16, 581-586.

Kawai, K., Tsuchiya, T. and Maruyama, S. (2010): The Second continent. Journal of Geography (Chigaku Zasshi), 119, 1197-1214.

Kitajima, K., Maruyama, S., Utsunomiya, A. and Liou, J.G. (2001): Seafloor hydrothermal alteration at an Archean mid-ocean ridge. Journal of Metamorphic Geology, 19, 581-597.

Kobayashi, T. (1941): The Sakawa orogenic cycle and its bearing on the origin of the Japanese Islands. Journal of Faculty of Science, Imperial University of Tokyo, Sec. 2, 5, 219-578.

Komiya, T., Maruyama, S., Masuda, T., Nohda, S., Hayashi, M. and Okamoto, K. (1996): Plate tectonics at 3.8-3.7 Ga: Field evidence from the Isua accretionary complex, southern West Greenland. Journal of Geology, 107, 515-554.

Kunugiza, K., Maruyama, S. and Goto, A. (2011): Geotectonic evolution of the Hida Gaien belt, central Japan: Reconstruction of the oldest Pacific-type orogeny of Japan. Journal of Geography (Chigaku Zasshi), 120, in press.

Maruyama, S. (1990): Exhumation mechanism of highpressure metamorphic belts. 97th Annual Meeting of Geological Society of Japan Abstract, 484. (in Japanese.)

Maruyama, S. (1997): Pacific-type orogeny revisited; Miyashiro-type orogeny proposed. The Island Arc, 6 , 91-120.

Maruyama, S., Liou, J.G. and Terabayashi, M. (1996): Blueschists and eclogites of the world and their exhumation. International Geology Review, 38, 485594.

Maruyama, S., Santosh, M. and Zhao, D.P. (2007) : Superplume, supercontinent, and post-perovskite: mantle dynamics and anti-plate tectonics on the coremantle boundary. Gondwana Research, 11, 7-37. 
Maruyama, S., Masago, H., Katayama, I., Iwase, Y., Toriumi, M., Omori, S. and Aoki, K. (2010): A new perspective on metamorphism and metamorphic belts. Gondwana Research, 18, 106-137.

Maruyama, S., Omori, S., Senshu, H. and Kawai, K. (2011): Pacific-type orogeny revisited. Journal of Geography (Chigaku Zasshi), 120, in press.

Matsuda, Te. and Isozaki, Y. (1991): Well-documented travel history of Mesozoic pelagic cherts in Japan: From remote ocean to subduction zone. Tectonics, 10, 475-499.

Matsuda, T. and Uyeda, S. (1971): On the Pacifictype orogeny and its model: Extension of the paired meamorphic belts concept and possible origin of marginal seas. Tectonophysics, 11, 5-27.

Matsumoto, K., Sugimura, K., Tokita, I., Kunugiza, K. and Maruyama, S. (2011): Geology and metamorphism of the Itoigawa-Omi area of the Hida-Gaien belt, central Japan: Reconstruction of the oldest Pacific-type high P/T type metamorphism and hydration metamorphism during exhumation. Journal of Geography (Chigaku Zasshi), 120, in press.

Miyashiro, A. (1961): Evolution of metamorphic belts. Journal of Petrology, 2, 277-311.

Miyashiro, A. (1973): The Troodos complex was probably formed in an island arc. Earth and Planetary Science Letters, 122, 218-224.

Nakama, T., Hirata, T., Otoh, S., Aoki, K., Yanai, S. and Maruyama, S. (2010): Paleogeography of the Japanese Islands: Age spectra of detrital zircon and provenance history of the orogen. Journal of Geography (Chigaku Zasshi), 119, 1161-1172.

Nakamura, H. and Iwamori, H. (2010): Slab-derived fluid and magma generation in subduction zones. Journal of Geography (Chigaku Zasshi), 119, 10541062.

Naumann, E.H. (1885): Ueber den Bau und die Entstehung der japanische Inseln. Begleitworte zu den von der geologischen Aufnahme von Japan fuer den Berlin bearbeiten topographischen und geologischen Karten. Friedlaender and Sohn, 91S.

Nur, A. and Ben-Avraham, Z. (1982): Oceanic plateaus, the fragmentation of continents, and mountain building. Journal of Geophysical Research, 87B, 3644-3661.

Omori, S. and Isozaki, Y. (2011): Which does Paleozoic Japan belong to North or South China?: Wheredoes the Triassic collision zone in China pass through Korea and Japan?. Journal of Geography (Chigaku Zasshi), 120, in press.

Sakuyama, S. (2010): Cenozoic volcanisms and mantle dynamics in Japan: Progress in the last 10 year. Journal of Geography (Chigaku Zasshi), 119, 10631078.
Santosh, M. and Senshu, H. (2011): History of supercontinents and its relation to the origin of Japan. Journal of Geography (Chigaku Zasshi), 120, in press.

Scholl, D. and von Huene, R. (2007): Crustal recycling at modern subduction zone applies to the past-issues of growth and preservation of continental basement, mantle geochemistry, and supercontinent reconstruction. Geological Society of America Memoir, 200, 9-32.

Sedlock, R.L. and Isozaki, Y. (1990): Lithology and biostratigraphy of Franciscan-like chert and associated rocks in west-central Baja California, Mexico. Geological Society of America Bulletin, 102, 852-864.

Senshu, H., Maruyama, S. and Rino, S. (2010): Innovation of thermal evolution model of mantle. Journal of Geography (Chigaku Zasshi), 119, 1215-1227.

Suzuki, K., Maruyama, S., Yamamoto, S. and Omori, S. (2010): Have the Japanese Islands grown?: Five "Japan"s were born, and four "Japan"s subducted into the mantle. Journal of Geography (Chigaku Zasshi), 119, 1173-1196.

Tatsumi, Y., Sakuyama, M., Fukuyama, H. and Kushiro, I. (1983): Generation of arc basalt magmas and thermal structure of mantle wedge in subduction zone. Journal of Geophysical Research, 88B, 5815-5825.

von Huene, R. and Scholl, D.W. (1991): Observations at convergent margins concerning sediment subduction, subduction erosion, and the growth of continental crust. Reviews of Geophysics, 29, 279-316.

Wang, X.M., Liou, J.G. and Mao, H.K. (1989): Coesitebearing eclogites from the Dabie mountains in central China. Geology, 17, 1085-1088.

Yamamoto, S. (2010): Tectonic erosion: New perspectives on Pacific-type orogeny and continental growth models. Journal of Geography (Chigaku Zasshi), 119, 963-998.

Yamamoto, S., Nakajima, J., Hasegawa, A. and Maruyama, S. (2009): Izu-Bonin arc subduction under the Honshu island, Japan: Evidence from geological adn seismological aspect. Gondwana Research, 16, 572580.

Yamato-Omine Research Group (1981): PaleozoicMesozoic rocks in the central Kii peninsula. Guidebook for Excursion Annual Meeting of the Association for the Geological Collaboration in Japan, 88p.

Yanai, S., Aoki, K. and Akahori, Y. (2010): Opening of Japan Sea and major tectonic lines of Japan: MTL, TTL and Fossa magna. Journal of Geography (Chigaku Zasshi), 119, 1079-1124.

Zhao, D.P. (2004): Global tomographic images of mantle plumes and subducting slabs: insight into deep Earth dynamics. Physics of the Earth and Planetary Interiors, 146, 3-34. 